\title{
Pemahaman Jamaah tablig terhadap Ayat-Ayat Dakwah dan Implikasinya terhadap Konsep Khurüj dan Jawlah
}

\author{
Abdul Hakim Wahid \\ UIN Syarif Hidayatullah Jakarta \\ hakim.wahid@uinjkt.ac.id \\ Ahmad Muhaimin \\ UIN Syarif Hidayatullah Jakarta \\ ahmad.muhaemin15@mhs.uinjkt.ac.id
}

\begin{abstract}
This article aim to disclose and understand the concept of dakwah implemented by the Dakwah movement in the Kebon Jeruk mosque, and to know how their understanding of the verses referred as evidence arises some concepts of dakwah done such as khurüj, and the verses that are a foothold to preach with the concept of Jawlah. Based on the results of the research, concluded that the verses of Dakwah which are referenced and understood by the jamaah tablig are essentially the same as most other dakwah movements. In understanding some verses that are then used as the basis of their arguments, it can be said that they are more looking at the literal-textual aspect, rather than the substantive-contextual meaning. And for the emergence of the concept of Dakwah with the name Khurüj and Jawlah, is a representation of the Prophet and his companions Dakwah when spreading Islam in the Mecca, and not based on Qur'an.
\end{abstract}

Keywords: Jamaah tablig, Khurūj, Jawlah, Dakwah

\begin{abstract}
Abstrak: Artikel ini ingin mengungkap dan memahami konsep pelaksanaan dakwah gerakan Jamaah tablig Masjid Jami' Kebon Jeruk, dan mengetahui bagaimana pemahaman mereka terhadap ayatayat yang dirujuk sebagai dalil, sehingga muncul beberapa konsep dakwah yang dilakukan dengan cara khurüj, dan ayat apa saja yang menjadi pijakan berdakwah dengan konsep jawlah. Berdasarkan hasil penelitian yang telah dilakukan, disimpulkan bahwa ayat-ayat dakwah yang dirujuk dan dipahami Jamaah tablig pada dasarnya sama dengan kebanyakan gerakan dakwah lainnya. Dalam memahami sejumlah ayat yang kemudian dijadikan sebagai basis argumennya, dapat dikatakan bahwa mereka lebih melihat kepada aspek literal-tekstual dari pada makna substanstif-kontekstual. Adapun lahirnya konsep dakwah dengan nama khurüj dan jawlah, merupakan suatu bentuk representasi dari cara meneladani dakwah nabi bersama para sahabatnya pada saat menyebarkan risalah agama Islam di kota Mekkah, dan bukan berdasarkan ayat al-Qur'an.
\end{abstract}

Kata Kunci: Jamaah tablig, Khurūj, Jawlah, Dakwah. 


\section{Pendahuluan}

Pada awal tahun 1980-an, terjadi perkembangan dakwah di Indonesia, dengan banyaknya elemen pergerakan dakwah Islam dari luar negeri dengan berbagai corak pergerakan yang berbeda datang ke Indonesia untuk menyampaikan ajaran Islam. Ada gerakan yang bertujuan untuk mengubah masyarakat dari seluruh tatanan kehidupan sosialnya mulai dari elit-elit politik hingga pada sistem pemerintahannya. Ada juga gerakan dakwah yang hanya fokus pada peningkatan spiritualitas dan peningkatan ibadah, namun tidak menyentuh sikap dan kehidupan politik, seperti jamaah tablig. ${ }^{1}$

Kelompok dakwah ini pertama kali datang pada 1915 ke masjid al-Hidayah Medan yang dipimpin oleh Miaji Isa dengan menamakan kelompoknya sebagai Jamā'ah Khurūj, yaitu jamaah yang keluar di jalan Allah untuk melatih memperbaiki diri, dan mengajak masyarakat untuk taat kepada Allah. ${ }^{2}$ Gerakan ini semakin nyata menunjukkan keberadaan-nya pada tahun 1974 dengan pusatnya di masjid Kebon Jeruk Jakarta. Dengan adanya markas ini menunjukkan bahwa jamaah tablig di Indonesia telah mendapatkan tempat dan tanggapan positif, terlebih dengan banyaknya pengikut jamaah ini di Nusantara. Lebih dari

${ }^{1}$ Nurdin, Reaksi Sosial terhadap Pelaksanaan Khurūj Fi Sabilillah dalam Gerakan Dakwah Jamaah Tabligh di Kabupaten Gowa, (Skripsi Fakultas Ushuluddin, Filsafat dan Politik Universitas Islam Negeri Alauddin Makassar, 2017), 7.

2 Abdul Aziz, "The Jamaah Tabligh Movement in Indonesia," Studia Islamika, 11: 3, 2004.

3 Yusran Razak, Jamaah Tabligh, Ajaran dan Dakwahnya, Disertasi Doktor, Sekolah Pascasarjana UIN Syarif Hidayatullah Jakarta, 2008, 60, sebagaimana dikutip oleh Umdatul Hasanah, Keberadaan Kelompok Jamaah Tabligh dan Reaksi Masyarakat (Perspektif Teori Penyebaran Informasi dan Pengaruh), 22.

${ }^{4}$ Dakwah dengan metode silaturahmi memiliki berbagai kelebihan. Kunjungan dakwah semacam ini itu, lembaga kaderisasi dari jamaah tablig juga telah didirikan yang dipusatkan di Pondok Pesantren Al-Fatah, Magetan, Jawa Timur. ${ }^{3}$

Metode utama dakwah yang dilakukan jamaah tablig ialah metode silaturahim. ${ }^{4}$ Dakwah dengan melalui silaturahmi ini dilakukan oleh jamaah tablig dalam sebuah konsep dakwah yang dinamai Jawlah. $^{5}$ Berdakwah dengan cara menyambangi tiap pintu rumah ini kemudian menjadi ciri khas dari sebuah pola dakwah yang dilakukan rombongan jamaah tablig ketika mengunjungi suatu daerah.

Landasan yang digunakan jamaah tablig untuk berdakwah, merujuk pada beberapa ayat seruan berdakwah dalam al-Qur' an, antara lain yang termaktub dalam QS. Āli 'Imrān [3]: 110, dan QS. al-Tawbah [9]: 24, sebagai berikut:

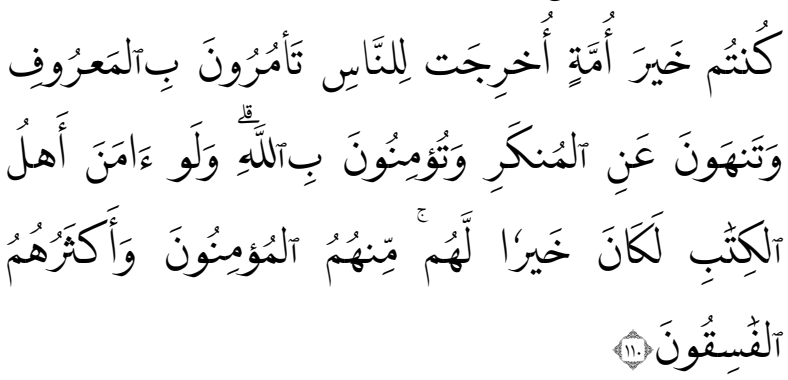

"Kamu adalah umat yang terbaik yang dilahirkan untuk manusia, menyuruh kepada yang ma'ruf, dan mencegah dari yang munkar, dan beriman kepada Allah. Sekiranya Ahli Kitab beriman, tentulah itu lebih baik bagi

dapat menciptakan hubungan yang lebih akrab antara da' $i$ dan mad'u, terutama bila keduanya saling mengenal. Bila mereka belum saling mengenal, maka dapat terjalin persahabatan atas dasar keimanan yang kemudian berbuah menjadi persaudaran. Interaksi semacam ini mungkin tidak ada dalam dakwah dengan metode ceramah atau yang lainnya. Ali Mustafa, "Model Dakwah Silaturahmi Jamaah Tabligh dalam Jawlah Khususi", Jurnal As-Salam, 2017, Vol. I, 81.

5 Jawlah ialah sebuah metode dakwah yang dilakukan Jamaah Tabligh dengan cara berkeliling mendatangi setiap rumah di sebuah kampung tertentu untuk menyampaikan pesan-pesan dakwaAli Mustafa, Model Dakwah Silaturahmi Jamaah Tabligh dalam Jawlah Khususi. Jurnal As-Salam, 84. 
mereka, di antara mereka ada yang beriman, dan kebanyakan mereka adalah orang-orang yang fasik."

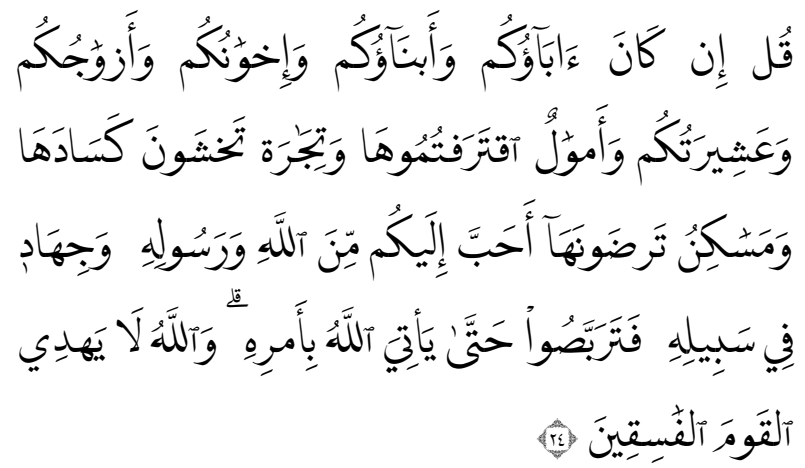

Katakanlah: "jika bapak-bapak, anak-anak, saudara-saudara, isteri-isteri, kaum keluargamu, harta kekayaan yang kamu usahakan, perniagaan yang kamu khawatiri kerugiannya, dan tempat tinggal yang kamu sukai, adalah lebih kamu cintai dari Allah dan Rasul-Nya dan dari berjihad di jalan-Nya, maka tunggulah sampai Allah mendatangkan keputusan-Nya". Dan Allah tidak memberi petunjuk kepada orang-orang yang fasik.

Ayat-ayat di atas, dipahami oleh Jamaah tablig sebagai perintah untuk berjihad dalam berdakwah yang kemudian menjadi landasan untuk melakukan khurūj, yaitu meluangkan waktu untuk pergi keluar meninggalkan rumah yang biasanya dalam kurun waktu 3 hari, 7 hari, 40 hari, hingga 4 bulan, dengan meninggalkan keluarga dan kampung halaman

${ }^{6}$ Abdurrahman As-Sirbuny, Kupas Tuntas Jamaah Tabligh (Cirebon: Pustaka Nabawi, 2012), 147.

${ }^{7}$ Rasyid Ridha misalnya. Ketika menafsirkan Ali Imran[3]:104, beliau berpendapat bahwa dalam urusan berdakwah tidak boleh diserahkan kepada sembarang orang, tugas ini harus dimandatkan kepada kelompok profesional (khawwas al-ummah) yang memahami perincian ajaran agama dan pemahamannya. Rashīd Riḍā, Tafsīr Al-Qur'ān al-Hakìm al-Syahir bi al-Tafsīr al-Manār (Kairo: Hai'ah Misriyyah al-'Ammah li alKitab, 1990), juz 4, 23.

8 Dikutip dari https://almanhaj.or.id/1221jamaah-Tabligh-tidak-berdiri-berdasarkan-kitabullahdan-sunnah-rasulnya.html diakses pada Selasa, 05 demi menjalankan tugas berdakwah ke seluruh pelosok daerah bahkan ke luar negeri. ${ }^{6}$

Banyak kalangan yang menilai negatif terhadap eksistensi gerakan dakwah jamaah tablig. Selain pemahaman Jamaah tablig perihal ayat-ayat dakwah yang dinilai berseberangan dengan penjelasan mayoritas ulama tafsir, ${ }^{7}$ karena tidak mendasarkan penafsirannya terhadap sumber-sumber yang otoritatif, seperti kaidah tafsir, prinsip-prinsip Ulum Al-Qur'an, dan lain sebagainya, gerakan ini juga acapkali mendapat klaim bid'ah dan sesat dari beberapa ulama oleh sebab amalan yang dipraktikan tidak berdasarkan al-Qur'an dan sunnah, Sehingga menyebabkan metode dakwah jamaah tablig ditentang keras dan timbul larangan terhadap umat Islam untuk mengikuti ajarannya. ${ }^{8}$ Persoalan lain juga muncul dari aktivitas Khurūj untuk berdakwah yang seiring waktu mengundang reaksi sosial negatif terhadap gerakan jamaah tablig. ${ }^{9}$

Berdasarkan penjajakan masalah di atas, penulis mengamati bahwa permasalahan yang berdampak kepada pola dan cara berdakwah jamaah tablig bisa jadi berakar dari pemahaman mereka terhadap ayat-ayat dakwah, sehingga menimbulkan rasa penasaran untuk mengkaji dan meneliti persoalan ini secara lebih mendalam.

Maret 2019. Kritikan semacam ini juga selaras dengan fatwa Nashiruddin Albany tentang Jamaah Tabligh yang ditulis oleh Abu Umamah Abdurrahim al Atsary dalam buku Jamaah Tabligh; kenyataan dan pengakuan, (Yogyakarta: Hikmah Ahlussunnah, 2015), 52.

${ }^{9}$ Akar permasalahan ini biasanya timbul berkaitan dengan keharmonisan dan kesejahteraan keluarga pengikut Jamaah Tabligh yang ditinggalkan beberapa lama untuk Khurüj berdakwa. Lihat Nurdin, "Reaksi Sosial Terhadap Pelaksanaan Khurūj Fi Sabilillah dalam Gerakan Dakwah Jamaah Tabligh di Kabupaten Gowa, Makassar: Studi Living Quran", (Skripsi S1 Fakultas Ushuluddin, Universitas Islam Negeri Alauddin Makassar 2017). 10. 


\section{Metode}

Dalam rangka mengetahui akar permasalahan pemahaman jamaah tablig, penulis melakukan observasi partisipatif dengan melibatkan diri ikut serta dalam satu rombongan jamaah yang berasal dari markas pusat gerakan jamaah tablig Indonesia, yaitu jamaah Masjid Jami' Kebon Jeruk Jakarta Barat yang akan Khurūj selama 7 hari dan singgah ke dua lokasi, yaitu Musholla An-Nur yang beralamat di Jl. Pendidikan, RT. 03/RW. 03, Rempoa, Ciputat timur, Tangerang Selatan, dan Masjid Jami Darussalamah, yang berlokasi di Jl. Bintaro Selatan, Blok N1, No. 1, RT. 11/RW. 11, Bintaro, Pesanggrahan, Kota Jakarta Selatan.

Selama 7 hari tersebut penulis mengamati dan melakukan wawancara kepada anggota rombongan dengan mengajukan pertanyaan mengenai alasan mengikuti kegiatan, bertanya tentang pengetahuan, dan pemahaman mereka tentang ayat-ayat dakwah dengan mengajukan 10 pertanyaan kepada setiap orang dengan komposisi 3 pertanyaan seputar alasan mengikuti kegiatan, dan 7 pertanyaan tentang pengetahuan serta pemahaman mereka terhadap ayat-ayat dakwah dalam al-Qur'an.

Kemudian untuk menganalisis data penelitian, digunakan metode penafsiran (interpretatif analityc). Metode ini merupakan sebuah metode analisis data sebagai upaya untuk menjelaskan tentang apa yang dikatakan oleh informan dan menafsirkan kembali penjelasan dan aktifitas tersebut berdasarkan

10 Moh. Soehadha, Metode Penelitian Sosial Kualitatif untuk Studi Agama, 138.

${ }^{11}$ Khusniati Rofiah, Dakwah Jamaah Tabligh dan Eksistensinya di Mata Masyarakat, STAIN Ponorogo Press. 48-49; Sayyid Abul Hasan al-Nadwi, Riwayat Hidup dan Usaha Dakwah Maulana Muhammad Ilyas, 15; Angga Kurniawan, Teologi Jama'ah Tabligh (Studi Kasus di Pesantren Sunanul penafsiran peneliti. $^{10}$ Semua data yang dihasilkan selanjutnya disajikan dengan pendekatan deskriptif kualitatif.

\section{Sejarah Gerakan Jamaah tablig dan Prinsip Ajarannya}

Jamaah tablig didirikan oleh Muhammad Ilyas al-Kandahlawy, (18851944), seorang pengikut mazhab Hanafi, yang disebabkan oleh kerisauannya terhadap kondisi umat Islam pada masa itu yang jauh dari syariat Islam, agama dan dakwah. Kondisi masyarakat yang sangat miskin dan sulit untuk diajak maju dalam bidang pendidikan, menjadi inspirasi untuk membentuk delegasi dakwah, ${ }^{11}$ dan mengirimnya ke kampung-kampung untuk jawlah (berkeliling dari rumah ke rumah). ${ }^{12} \mathrm{Di}$ mulai dari tenah kelahirannya, Mewat, kemudian secara berangsur-angsur usaha tablig itu meluas ke daerah-daerah lain di India dan ke daerah Asia Barat. Di bandar-bandar pelabuhan banyak jamaah yang dikirim kemudian tinggal dan terus bergerak menuju tempat-tempat yang ditargetkan. Setelah jamaah ini terbentuk, mereka lantas memperluas sayap dakwah dengan membentuk beberapa jaringan di sejumlah negara termasuk di Indonesia.

Di Indonesia, kegiatan tablig dan dakwah jamaah tersebut terpusat di Masjid Kebon Jeruk. ${ }^{13}$ Di masjid tersebut berkumpul jamaah dari berbagai daerah, bahkan dari berbagai negara. Mereka memiliki ciri-ciri berjenggot, mengenakan baju koko, surban atau peci putih, dan celana mereka tidak ada

Husna Manjangan), Skripsi Fakultas Ushuluddin, UIN Jakarta, 2017. 22.

${ }^{12}$ Sayyid Abul Hasan al-Nadwi, Riwayat Hidup dan Usaha Dakwah Maulana Muhammad Ilyas, 40.

${ }^{13} \mathrm{http}: / /$ mesjidjamikebonjeruk.blogspot.com/200 9/09/artikel-masjid-kebon-jeruk.html pada Rabu, 06 Maret, 2019. 
yang menutupi mata kaki. Banyak juga yang memakai baju panjang sampai ke lutut, sambil membawa tasbih yang selalu berputar di tangan dan aroma minyak cendana atau kasturi. Profesi jamaah tabligh berbagai macam, ada pimpinan pondok pesantren, pejabat pemerintah, pedagang kaki lima, pengusaha, mantan preman, artis hingga mahasiswa, mereka secara rutin mendengarkan ceramah setiap usai shalat maghrib. Ada dua amalan yang harus dikerjakan oleh para jamaah, yakni amalan Infirādî dan Ijtimā'ì. Pada amalan infirād $\bar{\imath}$, setiap orang menjalankan ibadahnya sendirisendiri, seperti Shalat Dhuha, Shalat Tahajud, Shalat Israq, membaca Al-Qur'an setiap hari minimal 1 Juz, dan melakukan dzikir sepanjang hari. Sedangkan amalan Ijtimā' $\hat{\imath}$, adalah amalan yang dilakukan secara bersamasama, seperti menjalankan shalat fardu, dan menghadiri dua majlis wajib, yaitu majelis Khurghazi $i^{14}$ dan majelis Bayan. ${ }^{15}$

Masjid Jami' Kebon Jeruk memiliki fungsi ganda, yaitu sebagai markas jamaah tablig dan sebagai lembaga penerima (host institution) bagi pengikut jamaah tablig dari berbagai negara. Pada fungsi pertama, masjid ini menjadi tempat I'tikâf dan pelayanan bagi pengikut jamaah tablig dari seluruh Indonesia. Pada setiap Kamis malam, masjid ini dipenuhi sekitar 1000-an jamaah dari berbagai halaqah daerah di Jakarta dan luar Jakarta. Saat ini terdapat sekitar 170 halaqah di seluruh DKI Jakarta. Setiap halaqah melayani antara 20

14 Majelis Khurgazi adalah suatu majelis yang berupa kesaksian seseorang yang baru pulang dari perjalanannya di jalan Allah dan mengajak para jamaah untuk ikut melakukan perjalanan ini. Biasanya majelis ini diadakan setelah Shalat Ashar sampai jam setengah lima sore.

15 http://mesjidjamikebonjeruk.blogspot.com/ 2009 /09/artikel-masjid-kebon-jeruk.html pada Rabu, 06 Maret, 2019. hingga 40 masjid.. Setiap hari, masjid ini menerima pendaftaran (tasykill) dari anggota Jamaah tablig untuk perjalanan dakwah keluar (khurūj). Anggota Jamaah tablig ini dimasukkan dalam beberapa kelompok dengan jumlah 5 orang setiap kelompok, yang terdiri dari beberapa posisi yakni: 1) Amīr (pemimpin kelompok), Mutakallim (juru bicara), 3) Dalīl (penunjuk jalan atau tuan rumah), 4) Makmūr (pemberi bayan atau ceramah). Keputusan tentang berapa kelompok, siapa saja yang menempati posisi dalam setiap kelompok dan daerah sasaran dibacakan pada kegiatan musyawarah setiap selesai sholat Isya.

Fungsi kedua, masjid ini sebagai lembaga penjamin (host institustion) yang menguruskan izin tinggal bagi pengikut Jamaah tablig yang berasal dari luar negeri. Masjid ini juga menyediakan ruang khusus untuk mereka di lantai 3 masjid selama mereka menunggu proses pengurusan surat-surat yang dibutuhkan. ${ }^{16}$ Seluruh jamaah tablig yang penulis temui, baik anggota dari dalam maupun luar negeri, semuanya hampir sepakat bahwa dakwah adalah kewajiban setiap Muslim dan Muslimah, bukan hanya tugas bagi Ulama, Ustadz, Kyai dan Habib, Syekh atau orang yang memilki ilmu agama luas.

Jamaah ini memiliki misi ganda yaitu peningkatan kualitas individu dan mendakwahkan kebesaran Allah Swt., kepada seluruh umat manusia. ${ }^{17}$ Dalam melaksanakan dakwah, jamaah tablig memiliki enam prinsip yang diberi nama dengan enam sifat para

16 Wawancara dengan Ust. Muhmmad Yunus, S.Ag yang merupakan anggota syuro Jamaah Masjid Kebon Jeruk sekaligus Amir Jamaah rombongan penulis, pada 13 Januari 2019, di Mushalla An-Nur, Cirendeu, Tangerang Selatan.

${ }^{17}$ Sayyid Abul Hasan al-Nadwi, Riwayat Hidup dan Usaha Dakwah Maulana Muhammad Ilyas, 39. 
sahabat. Prinsip-prinsip tersebut juga mendasari pemahaman mereka terhadap ayatayat dakwah. Menurut mereka, umat Islam yang tidak mengamalkan 6 prinsip ini, dianggap belum mengamalkan agama secara sempurna. Bagi mereka, para sahabat telah berhasil mengamalkan agama dengan sempurna karena memiliki enam sifat tersebut. Oleh karena itu, Jamaah tablig meyakini bahwa akan ada kekuatan untuk mengamalkan agama dengan sempurna apabila seseorang memiliki enam sifat sahabat tersebut. Keenam sifat tersebut adalah sebagai berikut:

1. Yakin terhadap kalimat Tayyibah ( $L \bar{a}$ Ilāha Illa Allāh Muhammad alRasullullāh). Dalam keyakinan ini, Jamaah tablig merujuk kepada sebuah hadis yang menjelaskan keuntungan dari meyakini kalimat Là Ilāh Illa Allāh. Selain itu, prinsip tersebut juga merujuk kepada sebuah hadis yang menjelaskan keuntungan dari menghidupkan sunnah-sunnah Nabi Muhammad saw. Bagi Jamaah tablig, ada 3 cara untuk mendapatkan keyakinan tersebut, yaitu: pertama, selalu mendakwahkan pentingnya sunnah Rasulullah saw. kedua, latihan dengan cara selalu menghidupkan sunnah-sunnah Rasulullah saw dalam kehidupan sehari-hari, yang terdiri dari: (1) Surah: penampilah Rasulullah saw, (2) Sirah: perjalanan hidup Rasulullah saw, (3) Sarirah: pikir dan kerisauan Rasululullah saw. ketiga,

18 An Nadhr M. Ishaq Shahab, Khurūj Fi Sabilillah (Bandung: Pustaka Ramadhan, 2007), 90; Maulana Muhammad Yusuf al-Kandahlawi, Mudzakaroh Enam Sifat Para Sahabat dan Amalan Nurani (Bandung: Pustaka Ramadhan, 2006), 5.

19 Moh. Ardani, Akhlak Tasawuf: Nilai-Nilai Akhlak/Budi Pekerti dalam Ibadat dan Tasawuf, (Jakarta: CV. Karya Mulia, 2005), 11. berdoa kepada Allah swt agar diberi taufik dan hidayah sehingga dapat mengamalkan sunnah - sunnah Rasulullah saw. ${ }^{18}$

2. Shalat khusyu' dan khudu'. Khusyü', prinsip ini didasarkan pada pandangan bahwa norma-norma syariat di dalam pelaksanaan ibadah, jika dihayati dan dilaksanakan dengan ikhlas akan membawa pengaruh positif pada moral. ${ }^{19}$ Shalat dengan khudu' dalam pandangan jamaah tablig adalah tertib waktu shalat, tertib tempatnya di mana saja adzan dikumandangkan, dan tertib pelaksanannya dengan cara berjamaah. ${ }^{20}$ Syeikh al-Kandahlawi menjelaskan bahwa cara mendapatkan manfaat dari shalat khusyū' dan khudu' ada 5, pertama, selalu mendakwahkan pentingnya shalat khusyū' dan khudu'. Kedua, memperbaiki tertib zahir shalat dari mulai istinja', wudhū', hingga bacaan-bacaan dan gerakan-gerakan shalat. Ketiga, menghadirkan keagungan Allah swt ke dalam hati ketika sedang melakukan shalat. Keempat, belajar menyelesaikan masalah dengan shalat. Kelima, berdoa kepada Allah swt agar diberi taufik untuk mengerjakan shalat dengan khusyü, dan khudu' ${ }^{21}$

3. Ilmu serta zikir. Maksud dari ilmu dan zikir ini adalah untuk mengetahui, memahami, dan mengamalkan seluruh perintah Allah swt setiap saat dan

20 Moh. Ardani, Akhlak Tasawuf: Nilai-Nilai Akhlak/Budi Pekerti dalam Ibadat dan Tasawuf, 12

21 Maulana Muhammad Yusuf al-Kandahlawi, Mudzakaroh Enam Sifat Para Sahabat dan Amalan Nurani, 8. 
dalam keadaan apapun setiap hari. ${ }^{22}$ Prinsip ini, merujuk kepada beberapa ayat al-Qur'an yang menjelaskan kentungan dari berilmu dan berdizkir. Bagi jamaah tablig, pengetahuan yang disukai Allah adalah pengetahuan yang menjadikan manusia dekat denganNya, karena itu, mereka selalu berusaha agar dapat belajar dan berzikir karena ilmu tanpa zikir merupakan kejahilan sedangkan zikir tanpa ilmu lebih berbahaya dari pada kelalaian. Oleh sebab itu, anggota Jamaah tablig selama beberapa hari meninggalkan rumah tangganya karena ingin mencari ilmu tentang Islam agar dimuliakan oleh Allah sebagai orang yang berjihad di jalan Allah swt. ${ }^{23}$ Syeikh al-Kandahlawi menjelaskan bahwa cara mendapatkan keuntungan dari keutamaan zikir adalah pertama, selalu mendakwahkan pentingnya zikir. Kedua, istiqamah membaca alQur'an setiap hari. Ketiga, berdikir istighfār, tasbīh, tahmīd, tahlīl, takbīr, dan șalawat sekurang-kurangnya seratus kali tiap pagi dan petang. Keempat, mengamalkan doa-doa masnunah (sunnah) dalam setiap kegiatan sehari-hari. Kelima, berdoa kepada Allah swt agar diberi hajat (perasaan butuh) kepada zikir. ${ }^{24}$

4. Ikrām al-Muslimīn. ialah memuliakan sesama muslim, tanpa mengharap hakhak kita ditunaikan, dengan berakhlak baik terhadap manusia maupun kepada

22 An Nadhr M. Ishaq Shahab, Khurūj Fi Sabilillah, 100.

${ }^{23}$ Furqan Ahmad Ansari, Pedoman BerTabligh, (Malaysia: Dewan Pakistan 1995), 36.

24 Maulana Muhammad Yusuf al-Kandahlawi, Mudzakaroh Enam Sifat Para Sahabat dan Amalan Nurani, 19. makhluk yang lain. ${ }^{25}$ Syeikh alKandahlawi menjelaskan bahwa cara mendapatkan keutamaan ikrām almuslimīn adalah pertama, selalu mendakwahkan pentingnya ikrām almuslimīn. Kedua, memuliakan alim ulama, menghormati orang tua, menghargai sebaya dan menyayangi yang muda. Ketiga, memberi salam baik kepada orang yang dikenal ataupun orang yang tidak dikenal. Keempat, bergaul dengan orang-orang yang berbeda-beda wataknya. Kelima, berdoa kepada Allah swt agar dikaruniakan sifat Ikrām al-muslimīn ${ }^{26}$ Berkenaan dengan Ikrām al-Muslimīn, Jamā'ah Tablīgh mengutip ayat dalam QS. al-Hujurāt ayat 10

5. Taṣhīh al-Niyyah (ikhlas), Keihklasan dalam setiap amal sangat penting, karena amal yang dikerjakan tanpa dilandasi keikhlasan maka tidak ada nilainya di sisi Allah swt walaupun amalan tersebut banyak. Adapun sebaliknya, amal yang dikerjakan dengan keikhlasan walaupun sedikit maka sangat tinggi nilainya di sisi Allah swt. ${ }^{27}$ Syeikh al-Kandahlawi menjelaskan bahwa cara mendapatkan keutamaan taṣhịh al-niyyah adalah pertama, selalu mendakwahkan pentingnya ikhlas dan memperbaiki niat. Kedua, memperbaiki niat dengan cara memeriksa niat sebelum beramal, ketika sedang beramal dan setelah beramal. Ketiga, berdoa kepada Allah

25 An Nadhr M. Ishaq Shahab, Khurūj $F \bar{\imath}$ Sabilillah, 108.

${ }^{26}$ Maulana Muhammad Yusuf al-Kandahlawi, Mudzakaroh Enam Sifat Para Sahabat dan Amalan Nurani, 23.

27 An Nadhr M. Ishaq Shahab, Khurūj $F \bar{\imath}$ Sabilillah, 112. 
Swt agar ditanamkan sifat ikhlas ke dalam hati. ${ }^{28}$ Prinsip ini didasarkan pada QS. 'Ali Imrān [3]: 145).

6. Dakwah, Tablīgh dan khurūj fì sabīl Allāh. Yakni mengajak dan menyampaikan pesan Islam dengan cara keluar di jalan Allah swt. Khurūj dalam pengertian di Jamaah tablig ini adalah bagi mereka yang keluar dari rumahnya yang nyaman untuk menyerukan kalimat Allah swt (tauhid) dan mengingatkan saudaranya (sesama muslim) agar kembali kepada ajaran agama secara käffah (menyeluruh) serta mengamalkan sunnah Nabi. Tujuan lainnya adalah amr ma'rūf nah̄̄ munkar ('ubūdiyah). Prinsip ini didasarkan pada ayat al-Qur'an yang menjelaskan tentang keuntungan berdakwah yaitu:
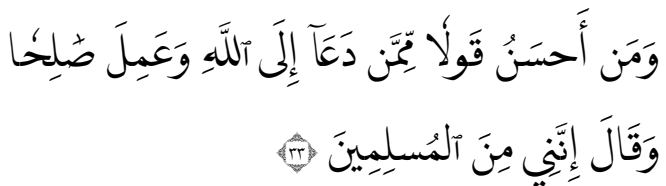

"Siapakah yang lebih baik perkataannya dari pada orang yang menyeru kepada Allah, mengerjakan amal yang saleh, dan berkata: "Sesungguhnya aku termasuk orangorang yang menyerah diri?." (QS. Fușilat [41]: 33)

Berdasarkan buku Faḍilah Amal yang merupakan buku utama Jamaah tablig dalam berdakwah, orang yang menyeru kepada agama Allah swt berhak mendapatkan kehormatan berupa berita gembira dan pujian seperti yang

28 Maulana Muhammad Yusuf al-Kandahlawi, Mudzakaroh Enam Sifat Para Sahabat dan Amalan Nurani, 25.

29 Maulana Muhammad Zakariyya, Fadhilah Amal, 342. disebutkan dalam ayat di atas. ${ }^{29}$ alKandahlawi menjelaskan bahwa cara untuk mendapatkan keutamaan dakwah ada 3 ; pertama, selalu mendakwahkan pentingnya dakwah al-tablīgh khurūj fì sabīl Allāh. Kedua, meluangkan waktu untuk keluar di jalan Allah swt. sekurang-kurangnya empat bulan seumur hidup, empat puluh hari setiap tahun, tiga hari setiap bulan, dan dua setengah jam setiap hari. Ketiga, berdoa kepada Allah swt agar diberi hakikat dakwah serta diberikan kekuatan untuk menjalankannya. ${ }^{30}$

Setelah mengetahui prinsip jamaah tablig, maka diketahui bahwa motivasi kuat mereka dalam berdakwah adalah karena setiap prinsip hanya dapat dihasilkan dengan cara mendakwahkannya kepada orang lain.

\section{Pemahaman Jamaah tablig mengenai Kewajiban Berdakwah}

Untuk mengetahui bagaimana pandangan Jamaah tablig tentang ayat-ayat dakwah, penulis telah meneliti tentang ayat mana saja yang sering digunakan oleh Jamaah tablig sebagai landasan untuk berdakwah. Merujuk kepada buku yang ditulis oleh Syaikh Maulana Muhammad Zakaria al-Kandahlawi, bahwa di antara banyaknya ayat-ayat dakwah dalam al-Qur'an, Jama'ah Tablig hanya mengutip tujuh ayat dan dua di antaranya adalah yang paling sering disampaikan dalam kegiatan bayān (ceramah setiap usai shalat fardhu). Dua ayat yang dimaksud adalah surat Āli 'Imrān ayat 104 dan $110 .{ }^{31}$

30 Maulana Muhammad Yusuf al-Kandahlawi, Mudzakaroh Enam Sifat Para Sahabat dan Amalan Nurani, 27.

${ }^{31}$ Maulana Muhammad Zakaria Al-Kandahlawi, Fadhilah Amal, terj. Tim Penerjemah Masjid Jami' 
Setelah mengetahui dua ayat yang dirujuk tersebut, selanjutnya penulis mewawancarai beberapa Jamaah terkait pandangan mereka terhadap makna dua ayat tersebut. Dalam memaknai ayat 104, seorang jamaah bernama Slamet Riyadi mengatakan:

“... Ayat ke-104 ini jelas, bahwa semua kita diperintahkan Allah swt untuk menyampaikan pesan ajaran agama, mengajak kepada kebaikan dan ketaatan kepada Allah swt, dan dakwah ini tidak terbatas hanya para ustadz dan ulama saja, tetapi semua kita, seorang bapak dalam sebuah keluarga contoh kecilnya, ia menjadi da'i bagi keluarganya...". 32

Senada dengan pendapat di atas, Sadelih menjelaskan pendapatnya sebagai berikut:

“... Ayat berdakwah dalam al-Qur'an surah Āli 'Imrān ini bermakna perintah Allah swt kepada kita agar mampu mensyiarkan ajaran Islam dengan caracara yang telah dicontohkan Rasulullah Saw dalam banyak riwayat. Kemudian dalam berjihad menyampaikan kebenaran ini pastinya banyak sekali godaan dan rintangan yang menghampiri. Mencintai urusan duniawi adalah salahsatu godaan yang harus kita tinggalkan ketika ingin benar-benar berdakwah dengan cara yang yang pernah nabi contohkan...".33

Rudi Asmi dengan lebih tegas menjelaskan pemahamannya tentang ayat tersebut sebagai berikut:

“... QS. Āli 'Imrān ayat 104 menegaskan bahwa Allah swt memerintahkan umat Islam supaya meluangkan waktunya untuk berdakwah

Kebon Jeruk Jakarta (Yogyakarta: Ash-Shaf, 2012), 342 .

32 Wawancara dengan pak Slamet Riyadi, pada 17 Januari 2019, di Masjid Darussalamah, Bintaro, Jakarta Selatan.

${ }^{33}$ Wawancara dengan Sadelih, pada 17 Januari 2019, di Masjid Darussalamah, Bintaro, Jakarta Selatan. menyampaikan kalimat Là Ilāha Illa Allāh dan mengajak muslim lain untuk kembali kepada ketataan. Maka dari itu, tugas untuk berdakwah ini tidak memandang pangkat, karena semua kita tentu ingin menjadi orang-orang yang disebutkan pada akhir ayat ini, yakni wa Ulà 'ika Hum al-Muflihūn. ${ }^{34}$

Penjelasan dan argumentasi Jamaah tablig di atas, mengindikasikan bahwa dalam memahami ayat seruan berdakwah dalam QS. Āli 'Imrān ayat 104 mereka lebih condong kepada penafsiran yang disampaikan oleh Sayyid Quțub dalam tafsirnya $F \bar{l}$ Zilāl alQur'ān yang menjelaskan bahwa kewajiban dakwah ini merupakan kewajiban individu bagi setiap muslim. Sayyid Quṭub menjelaskan bahwa dakwah merupakan konsekuensi logis dari iman. Iman dipandang eksis bila telah diwujudkan dalam bentuk amal saleh dan dakwah. Dalam tafsirnya, Sayyid Quṭub lebih menekankan pada penjelasan makna dari kata yad'ūna ilā al-khair dan ya'murūna bi alma'rūf wa yanhawna an al-munkar. Sayyid Quțub memahami bahwa dalam hal menyeru kepada kebaikan itu bisa disampaikan oleh siapa saja, kecuali untuk memerintah dan melarang haruslah oleh orang yang memiliki kekuasaan. Dari pandangan ini, berarti Sayyid Quțub dapat digolongkan dalam kelompok ulama yang mendukung hukum ganda dakwah, wajib individu, dan kolektif sekaligus. ${ }^{35}$

Pendapat Sayyid Quțub di atas berbeda dengan tafsir al-Qurțubī yang dalam penjelasannya fokus pada kalimat minkum. Menurutnya kata min pada kalimat minkum adalah untuk menunjukkan sebagian. Artinya

34 Wawancara dengan Rudi Asmi, pada 17 Januari 2019, di Masjid Darussalamah, Bintaro, Jakarta Selatan.

${ }^{35}$ Sayyid Quțub, Fi Zilāl al-Qur'ān, terj. Ainur Rafiq Shaleh Tamhid dan Syafril Halim, 347-348. 
bahwa, orang-orang yang berhak memerintahkan yang ma'rūf haruslah para ulama, karena tidak semua orang itu ulama yang memahami dan ahli dalam bidang agama, maka kewajiban dakwah bukanlah keajiaban setiap individu. Namun, al-Qurțubī juga tidak memungkiri bahwa ada pendapat lain yang mengatakan bahwa kata min adalah untuk menjelaskan jenis, maka makna yang dipahami adalah hendaknya kalian semua harus seperti itu. Terlepas dari itu, al-Qurțub̄̄ lebih setuju kepada pendapat yang pertama. Menurutnya, redaksi ayat ini menunjukkan bahwa amr ma 'rūf nahī munkar hukumnya fardhu kifayah. Allah telah menentukan kriteria mereka dalam firman-Nya QS. al-Hajj ayat 41, yang menjelaskan bahwa tidak semua orang diberikan keteguhan. ${ }^{36}$

Kemudian ketika penulis mewawancarai Jamaah tentang pemahaman mereka terkait QS. Āli 'Imrān ayat 110. Dari ketiga narasumber sebelumnya dan narasumber yang lainnya yaitu Syamsul Bachri dan Ahmad Fakhrurrazi, penulis menyimpulkan bahwa pandangan mereka memiliki kesamaan dengan pendapat Imam al-Qurțub̄ yang mengungkapkan bahwa kalimat "kuntum khaira ummatin ukhrijat li al-nās" adalah sebuah penghargaan dari Allah swt kepada umat ini, sehingga dengannya seorang muslim patut menjadi teladan bagi umat lain dengan cara menegakkan kebaikan dan meninggalkan keburukan serta melindungi umat dari segala hal yang menyebabkan kerusakan. ${ }^{37}$ AlQurțubī menjelaskan dalam tafsirnya bahwa konsekuensi pertama dari posisi ini ialah hendaknya ia melindungi kehidupan ini dari

${ }^{36}$ Syaikh Imam Al-Qurțubī, Al-Jāmi’ li Aḥkām Al-Qur'ān, terj. Dudi Rosyadi, dkk, 411.

37 Wawancara dengan Slamet, Rudi, Sadelih, Syamsul, dan Razi, pada 18 Januari 2019, di Masjid Darussalamah, Bintaro, Jakarta Selatan. keburukan dan kerusakan. Hendaknya ia memiliki keimanan yang kuat dan kekuatan yang memungkinkannya untuk melaksanakan amr ma 'rū f dan nahī munkar, karena ia adalah umat terbaik yang ditampilkan kepada seluruh manusia. Tugas untuk amr ma'rūf dan nahī munkar ini secara gamblang Allah sebutkan dalam lanjutan redaksi ayat tersebut dalam ungkapan: ta'murūna bi al-ma'rūf wa tanhawna an al-munkar wa tu'minūna billāh, menggalakkan kebaikan dan menentang keburukan dengan segenap kesulitan yang menyertai di jalannya, merupakan bagian dari tugas sebagai sebuah umat terbaik di sisi Allah swt. $^{38}$

Sementara itu, M. Quraish Shihab memberikan penjelasan dengan meninjau aspek asbāb al-nuzūl pada ayat 110 ini, bahwa ayat ini berkaitan dengan ayat ke-104 yang menjelaskan kewajiban berdakwah atas umat Islam. Menurutnya, pada ayat 104, persatuan dan kesatuan mereka yang dituntut, sedangkan dalam ayat 110 dikemukakan bahwa kewajiban dan tuntutan itu pada hakikatnya lahir dari kedudukan umat ini sebagai sebaikbaik umat. Ini yang membedakan umat Islam dengan Ahli Kitab yang justru mengambil sikap bertolak belakang dengan itu. Tanpa ketiga hal yang disebut oleh ayat ini, kedudukan mereka sebagai sebaik-baik umat tidak dapat dipertahankan. Adapun kata "kuntum khaira ummatin ukhrijat li al-nās" menegaskan bahwa Allah swt telah memberikan derajat paling tinggi kepada umat Nabi Muhammad saw sebagai umat terbaik di antara umat lainnya. Predikat umat terbaik ini seyogyanya dapat direpresentasikan dengan

38 Syaikh Imam Al-Qurțubī, Al-Jāmi' li Aḥkām Al-Qur'ān, 355-356. 
wajah sebuah umat yang penuh kebaikan dan keteladanan. Selain itu, dengan posisi tersebut tentu saja umat ini harus menyadari akan berbagai konsekuensi dan tanggung jawabnya. $^{39}$

Prinsip kuat Jamaah tablig dalam berdakwah tanpa memilah siapa yang ingin menjadi da'i, menjadi kekhasan tersendiri bagi gerakan dakwah yang satu ini, sehingga tidak heran jika anggota Jamaah tablig berasal dari berbagai kalangan, ada ustadz, pedagang, hingga kalangan akademisi dan artis. Meskipun sering mendapat kritikan perihal kompentensi seorang da'i, tetapi mereka tetap teguh dengan prinsip dakwah tersebut, dan itu merupakan salah satu daya tarik yang membuat pengikutnya terus bertambah.

\section{Landasan Jamaah tablig mengenai Khurūj untuk Berdakwah}

Definisi khurüj yang dimaksud dalam gerakan Jamaah tablig adalah keluarnya seseorang dari lingkungannya untuk memperbaiki diri dengan belajar mengelurkan sebagian harta dan meluangkan waktu dari kesibukannya di pekerjaan, keluarga, dan urusan-urusan lainnya, demi meningkatkan iman dan amal shalih karena Allah swt. ${ }^{40}$ Berkaitan dengan kata khurūj, asalnya dari khurūj fì sabīl Allāh yang secara literal berarti keluar di jalan Allah. Istilah ini diambil dari kata "ukhrijat" yang terdapat dalam surat Āli 'Imrān ayat 110, dan merujuk pada surat surat al-Șaf ayat 10-12. ${ }^{41}$

Berdasarkan definisi dan pengamatan penulis di lapangan, kegiatan khurüj ini bukan

${ }^{39}$ M. Quraish Shihab, Tafsir al-Misbah (Pesan, Kesan, dan Keserasian Alquran), 221.

40 Abdurrahman Ahmad As-Sirbuny, Kupas Tuntas Jamaah Tabligh, vol. 3, 147.

${ }^{41}$ Didi Junaedi, Memahami Teks, Melahirkan Konteks: Menelisiki Interpretasi Ideologis Jamaah Tabligh, 13. sekadar pergi keluar meninggalkan kampung halaman dalam rangka memperbaiki diri, tetapi juga sekaligus mengajak kaum muslim untuk bersama-sama mendengarkan kajian agama yang disampaikan di mushalla atau masjid setempat yang sekaligus sebagai markas berdakwahnya suatu rombongan. Aktivitas khurūj ini dipimpin oleh seorang amir yang dipilih berdasarkan musyawarah, ketaatan kepada amir menjadi kewajiban bagi setiap anggota rombongan, amir Jamaah yang memutuskan petugas-petugas dan mengatur arah dakwah selama $k h u r u \bar{j} .{ }^{42}$

Selama khurūj, kegiatan diisi dengan ta 'lim (membaca hadis atau kisah sahabat yang termuat dalam kitab Fadail Amal karya Maulana Zakaria), jawlah (mengunjungi rumah-rumah sekitar masjid dengan tujuan mengajak untuk mendengarkan kajian agama), ada pula bayān (ceramah usai shalat fardhu), mudzakarah (mengahafal 6 sifat sahabat), karkuzari (menyampaikan laporan harian kepada amir), dan musyawarah. ${ }^{43}$ Lamanya khurūj tergantung kesepakatan suatu rombongan sebelum berangkat, bilangannya antara 3 hari, tujuh hari, hingga 40 hari. Selama khurüj, Jamaah tinggal dan tidur di musholla atau masjid yang disinggahi. ${ }^{44}$

Menurut Azizullah Ilyas aktivitas khurūj dengan sendirinya dapat membentuk kepribadian seorang juru dakwah agar memiliki sifat personal positif seperti taat, sabar, taqwa, dan tawajjuh. Dengan melakukan kegiatan dan program khurūj serta mengorbankan waktu, diri dan harta untuk keperluan agama, diharapkan akan

\footnotetext{
${ }^{42}$ Hasil Observasi pada 14-17 Januari 2019, di Mushallla An-Nur, Cirendeu dan Masjid Darussalamah, Bintaro.

${ }^{43}$ Khusniati Rofiah, Dakwah Jamaah Tabligh dan Eksistensinya di Masyarakat. 79.

44 Hasil Observasi pada 15 Januari 2019, di Mushallla An-Nur, Cirendeu, Tangerang Selatan.
} 
mendatangkan sifat-sifat tersebut, karena sebagaimana disebutkan oleh Jamaah tablig bahwa kegiatan khurūj sendiri dimaksudkan sebagai sarana untuk memperbaiki umat secara bertahap. ${ }^{45}$ Selain itu, karena selama khurūj seseorang membiasakan diri dengan amal shalih, maka setelah mengikutinya, diharapkan dapat kembali mengamalkan semua amalan yang pernah dilakukan selama khurūj, semisal zikir, meramaikan masjid dengan suasana kajian agama, dan mengajak para tetangga berangat ke Masjid. Khurūj juga dinilai sebagai sarana untuk memperbaiki individu secara bertahap dan berkelanjutan yang nantinya akan membentuk manusia beriman yang memiliki kompetensi dalam berdakwah. ${ }^{46}$

Selanjutnya berkenaan dengan kegiatan $k h u r u \bar{j}$ yang menjadi ciri khas dalam gerakan ini, penulis mewawancarai amir Jamaah yang penulis ikuti, yaitu Ust. Yunus, dia berpendapat bahwa “... khurūj fi sabīl Allāh itu seperti usaha pertanian. Keluar tiga hari, tujuh hari, empat puluh hari, atau empat bulan, ibarat seorang petani yang mengolah sawah. Jika petani tidak mengikuti cara dan tata tertib pertanian, maka tidak akan dapat menghasilkan padi. Mengolah sawah lebih lama dari pada memanen hasil, mengolahnya juga memakan waktu tiga sampai empat bulan, sedangkan memanennya cukup dengan sehari. ${ }^{~} 47$

Adapun terkait ayat-ayat al-Qur'an yang dijadikan landasan untuk melaksanakan khurūj, penulis mewawancarai Sadelih, salahsatu Jamaah yang sudah lebih dari 25

45 M. Azizzullah Ilyas, "Kompetensi Juru Dakwah dalam Pandangan Jama'ah Tabligh", Jurnal Dakwah dan Komunikasi, Vol. 2, No. 01, Desember 2017.

46 Hasil Observasi pada 16 Januari 2019, di Mushallla An-Nur, Cirendeu, Tangerang Selatan. tahun berdakwah bersama Jamaah tablig Masjid Kebon Jeruk. Dia menyatakan: “... Di dalam al-Qur'an terdapat banyak sekali ayatayat yang menyeru kita untuk berdakwah, termasuk kisah-kisah Nabi terdahulu yang berdakwah dari satu wilayah ke wilayah lain, mereka berjuang demi tegaknya ajaran Islam. Maka, dengan ayat-ayat tersebut kita dapat mengambil hikmah dan keteladanan tentang perjuangan para Nabi untuk berdakwah. Antara lain seperti dalam QS. Hūd [11]: 51, QS. al-'Ankabūt [29]: 29, dan QS. Nūh [71]: 5-6..."48

Sejalan dengan Sadelih, Slamet Riyadi, menjelaskan pandangannya bahwa "Berdakwah dengan cara khurūj seperti ini adalah sebuah usaha mencontoh metode dakwah Rasulullah saw dan para sahabat yang rela meninggalkan keluarga, harta, dan tempat tinggal mereka demi berjihad menegakkan kalimat Lā Ilāha Illa Allāh. Tentu saja apa yang mereka lakukan berdasarkan seruanseruan Allah dalam al-Qur'an semisal surah 'Alī 'Imrān ayat 104 dan 110. Kemudian dalam al-Qur'an juga terdapat banyak sekali kisah-kisah perjuangan para Nabi terdahulu untuk menyampaikan risalah Islam, maka tidakkah kita sebagai umat terbaik ini ingin meneladani dan mengikuti cara perjuangan mereka dalam berdakwah?, QS. Yūsuf [12]: 108, QS. Hūd [11]: 51, QS. Nūḥ [71]: 5-6, QS. al-Ṣaf [61]: 10-11, QS. al-Tawbah [9]: 18, dan masih banyak lagi ayat lainnya yang dapat kita rujuk sebagai alasan berdakwah dengan cara seperti ini..." 49

47 Wawancara dengan Ust. Muhmmad Yunus, S.Ag, pada 17 Januari 2019, di Masjid Darussalamah, Bintaro, Jakarta Selatan.

48 Wawancara dengan pak Sadelih, pada 18 Januari 2019, di Masjid Darussalamah, Bintaro, Jakarta Selatan.

49 Wawancara dengan Slamet Riyadi, pada 18 Januari 2019, di Masjid Darussalamah, Bintaro 
Wawancara berikutnya penulis lakukan untuk menggali informasi terkait landasan hitungan hari dalam khurūj. Adalah Rudi Asmi, seorang Jamaah yang konsisten mengikuti khurüj bertahun-tahun dan telah berkeliling hingga ke mancanegara, ketika ditanya soal ketentuan jumlah hari dalam mengikuti khurūj, ia menjelaskan, “...Penetapan bilangan hari dan bulan untuk berdakwah di jalan Allah ini bukan sesuatu yang mengada-ngada, tetapi berdasarkan berbagai riwayat dan beberapa ayat al-Qur'an serta hadis yang berkaitan. Anjuran berdakwah dengan khurūj selama tiga hari misalnya, dulu, Rasulullah saw pernah mengirim Khalid bin Walid ke Banu Harits bin Ka'ab di Najran, beliau memerintahkan Khalid agar mau tinggal di kampung tersebut selama tiga hari dalam rangka mengajarkan ajaran Islam, maka setelah tiga hari berlalu, dengan izin Allah kampung tersebut banyak yang masuk Islam..."50

Rudi Asmi juga menambahkan bahwa penetapan bilangan khurüj hingga 40 hari pun merupakan bilangan yang telah banyak disebutkan dalam al-Qur'an seperti pada saat Nabi Musa as. pergi meninggalkan para sahabatnya selama 40 hari untuk menerima Taurat dari Allah di bukit Thur. Kisah tersebut termaktub dalam QS. al-A'rāf [7]: 147. Kemudian Rudi juga menjelaskan bahwa di balik penetapan bilangan hari untuk berdakwah ini mengandung banyak hikmah. Masa 40 hari yang dijalani oleh seseorang dalam suatu pendidikan dan suasana kebaikan, pasti akan berpengaruh besar bagi peningkatan kebaikan orang tersebut. Walaupun ini bukan suatu kewajiban dan keharusan, tetapi dengan lamanya seseorang berbaur dalam suasana

${ }^{50}$ Wawancara dengan pak Rudi Asmi, pada 17 Januari 2019, di Masjid Darussalamah, Bintaro, Jakarta Selatan. yang penuh dengan kesalihan dan ketaatan, maka seseorang dapat lebih meningkatkan ketakwaan dan keimanannya.

Berdasarkan penjelasan dan argumen jamaah yang telah dipaparkan berkaitan dengan khurūj di atas, dapat diketahui ayat mana saja yang mereka jadikan sebagai landasan untuk berdakwah dengan cara khurüj. Dalam ayat-ayat tersebut tidak terdapat penjelasan secara eksplisit tetang perintah $k h u r \bar{j}$, ayat-ayat itu menjelaskan tentang kisah dakwah para Nabi yang ikhlas dan tidak meminta bayaran dalam berdakwah, dan kesulitan yang mereka hadapi dalam mengajak kaumnya untuk beriman. Ayat-ayat itu juga menjelaskan tentang perintah untuk memakmurkan masjid, dan keuntungan orang beriman yang berjuang di jalan Allah dengan mengorbankan harta dan dirinya.

\section{Landasan Jamaah tablig dalam Praktik Jawlah}

Ketika khurūj dan menempati suatu masjid yang dijadikan sebagai titik berdakwah, jamaah tablig menyampaikan dakwahnya dengan cara jawlah, yakni berkeliling mengunjungi rumah-rumah di sekitar masjid tempat khurūj untuk bersilaturahmi sekaligus mengajak penghuni rumah mendengarkan ta'lim di masjid. Menurut salah satu anggota jamaah, metode dakwah dengan jawlah ini mengikuti cara Nabi saw dan para sahabatnya ketika menyebarkan Islam dari rumah ke rumah di kota Makkah. ${ }^{51}$

Berdasarkan observasi penulis, ketika tiba saatnya jawlah, rombongan jamaah dibagi menjadi 2 kelompok, satu kelompok di dalam masjid, dan satu kelompok lainnya di luar masjid. Anggota Jamaah yang di dalam masjid

51 Wawancara dengan Muhammad Yunus pada 15 Januari 2019. 
masing-masing bertugas sebagai: 1) Mudzakkir, berzikir dan berdo'a hingga kelompok yang di luar kembali, 2) Muqarrar, mengulang-ulang pembicaraan iman dan amal shalih dalam kitab fadhail amal, 3) Mustamī, mendengarkan pembicaraan taqrīr iman dengan seksama, 4), Istiqbāl, menyambut orang yang mendatangi masjid.

Sedangkan untuk kelompok yang di luar masjid, mereka diberi tugas sebagai: 1) Dalīl, penunjuk jalan, biasanya petugas ini adalah seorang karkun (warga setempat yang sebelumnya pernah atau sering mengikuti khurūj), 2) Mutakallim, menyampaikan materi dakwah ke tiap rumah yang dikunjungi, 3) Makmūr, berzikir dalam hati agar orang yang di rumah dilimpahkan hidayah Allah, kemudian apabila memang orang tersebut bersedia mengikuti ajakan, maka Makmūr mengantarkannya ke masjid, 4) Amīr Jawlah, bertanggungjawab terhadap perjalanan jawlah jamaah, dialah yang memutuskan rute dan durasi waktu jawlah. ${ }^{52}$

Berkaitan dengan alasan mengapa harus dengan cara jawlah, Yunus, selaku amir jamaah menjelaskan bahwa hal itu mengikuti tuntunan Nabi, di mana dalam shirah dakwah dinyatakan bahwa Rasulullah tidak pernah menunggu orang mendatangi beliau, melainkan beliau sendiri dan para da'i yang beliau kirim yang mendatangi mereka dan mendakwahkan ajaran agama. Yunus menambahkan bahwa dakwah dengan cara mendatangi rumah-rumah tentu akan banyak manfaat yang diraih. Menurutnya, tidak sedikit dengan melalui kunjungan ke rumah-rumah telah menyadarkan umat dari kelalaiannya selama ini, sehingga mereka mau bertaubat dan

${ }^{52}$ Hasil Observasi pada 14-18 Januari 2019, di Masjid Darussalamah, Bintaro, Jakarta Selatan berubah, serta mau melaksanakan shalat berjamaah. $^{53}$

Ketika ditanya mengenai ayat-ayat yang dijadikan dasar untuk melaksanakan jawlah, anggota jamaah tablig menyandarkannya pada 3 surat, yaitu: surat al-Nahl ayat 90, alSyu'ara' ayat 214, dan Surat al-Șaf ayat 10-11. Berikut ayat-ayatnya:

1. Surat al-Nahl ayat 90:

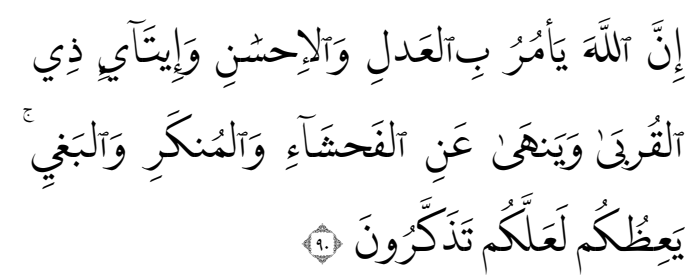

"Sesungguhnya Allah menyuruh

(kamu) berlaku adil dan berbuat kebajikan, memberi kepada kaum kerabat, dan Allah melarang dari perbuatan keji, kemungkaran dan permusuhan. Dia memberi pengajaran kepadamu agar kamu dapat mengambil pelajaran."

2. Surat al-Syu' ara' ayat 214:

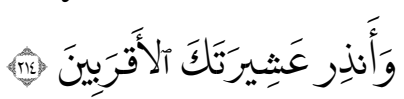

"Dan berilah peringatan kepada kerabat-kerabatmu yang terdekat.,

3. Surat al-Ṣaf ayat 10-11:

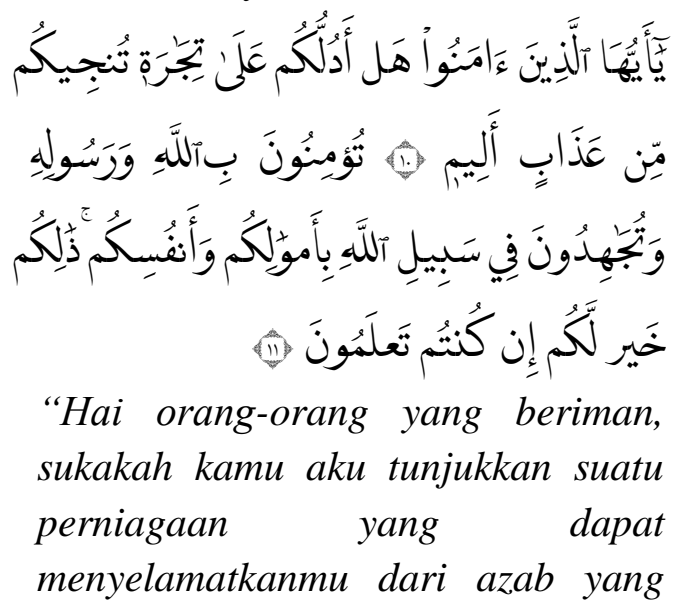

53 Wawancara dengan Muhmmad Yunus, pada 15 Januari 2019, di Mushalla An-Nur, Cirendeu, Tangerang Selatan. 
pedih? "(yaitu) kamu beriman kepada Allah dan Rasul-Nya dan berjihad di jalan Allah dengan harta dan jiwamu. Itulah yang lebih baik bagimu, jika kamu mengetahui"..

Anggota jamaah tablig menjelaskan bahwa selain didasarkan pada ayat-ayat tersebut yang juga merupakan landasan untuk Khurūj, metode jawlah ini juga mengikuti contoh yang dilakukan oleh Nabi Saw bersama para sahabat yang berjuang pantang menyerah demi menegakkan ajaran yang benar, meskipun dalam berdakwah itu, mereka dicemooh, diusir, dilempari kotoran, dan sebagainya. Meskipun di zaman sekarang metode dan alat dakwah sudah serba modern, bisa menggunaka media HP ataupun TV, tetapi berdakwah dengan cara yang pernah nabi praktekan, maka pastilah lebih besar keberkahannya. Selain itu, berdakwah mengikuti praktik Nabi akan membuat seorang da'i betul-betul merasakan apa yang dulu nabi rasakan dalam hal sulitnya mengajak orangorang untuk taat kepada perintah Allah Swt. Seruan Allah kepada nabi yang terdapat dalam ayat-ayat itu, juga merupakan seruan untuk umat Islam hari ini. Dengan berdakwah menggunakan metode jawlah (berkeliling dari satu pintu ke pintu lain), adalah salahsatu cara untuk mengamalkan sunnah nabi saw. ${ }^{54}$

Berdasarkan penjelasan dan beberapa argumentasi para narasumber di atas, maka dapat diketahui bahwa ayat-ayat di atas tidak menjelaskan secara eksplisit tentang perintah jawlah, dengan demikian dapat dikatakan bahwa anggota jamaah tablig menyampaikan

${ }^{54}$ Wawancara dengan Slamet Riyadi dan Sadelih pada 16 Januari 2019, di Masjid Darussalamah, Bintaro, Jakarta Selatan.

55 Kitab lain yang juga dijadikan pegangan standar bagi para pengikut Jamaah Tabligh ini adalah Hayat al-Sahabah, karya Mawlana Yusuf alKandahlawi, putra Maulana Muhammad Ilyas, serta ayat sebagai argumen secara serampangan tanpa mengetahui makna sesungguhnya dari ayat tersebut, dan hanya mengikuti ajaran yang terdapat dalam kitab pedoman yang mereka ketahui. Pelaksanaan jawlah oleh jamaah tablig dalam berdakwah adalah dalam rangka mengikuti prinsip ajaran dari pendirinya. Penjelasan yang benar terkait metode jawlah ini adalah sebuah metode yang mencontoh kepada cara dakwah nabi dan para sahabat.

\section{Refleksi Jamaah tablig dalam Memaknai dan Memahami Sebuah Ayat}

Setelah menguraikan ayat-ayat mana saja yang dikutip Jamaah tablig dalam dakwah, hingga prinsip khurüj, dan jawlah, selanjutnya dijelaskan pemahaman Jamaah tablig ketika menafsirkan sebuah ayat. Refleksi ini adalah gambaran pandangan mereka yang kemudian menjadi sebuah konsep dakwah lahir atas pembacaan mereka terhadap suatu ayat.

Penulis mengamati bahwa prinsip utama dakwah Jamaah tablig tak lain adalah membawa kesuksesan dan kejayaan umat manusia baik di dunia maupun di akhirat. Adapun sumber ajaran dari gerakan ini adalah al-Qur'an dan al-Sunnah. Sedangkan kitabkitab yang digunakan untuk melengkapi amalannya ialah kitab karangan para ulama salaf, seperti: Riyād al-Ṣaliḥin, Ihyyà' 'Ulūm alDìn, dan Fath al-Mu'in. ${ }^{55}$ Dengan demikian, tidak ada perbedaan yang prinsip antara gerakan Jamaah tablig dengan umat Islam pada umumnya.

Sebagaimana disinggung di bagian awal bahwa ketika Jamaah tablig memberikan

Muntakhab Ahadith, yang juga merupakan karya Maulana Yusuf al-Kandahlawi yang disusun kembali oleh Maulana Sa'ad al-Kandahlawi. Dalam kitab Muntakhab Ahadith inilah dijelaskan secara detail enam prinsip (ajaran) gerakan Jamaah Tabligh, yang kemudian mereka sebut dengan enam sifat sahabat. 
penjelasan perihal landasan mereka untuk menggerakan konsep dakwah ala nabi seperti khurüj dan jawlah, maka argumentasi yang disampaikan ialah merujuk kepada ayat-ayat yang secara teks tidak berkaitan dengan yang mereka maksud. Misalnya ketika memahami QS. Hūd ayat 51 yang secara terjemahan adalah perintah Allah kepada umat nabi Hūd as. yaitu kaum 'Ad kemudian dipahami sebagai anjuran untuk khurūj, atau ketika menyebutkan bahwa metode jawlah berdasarkan QS. Nūḥ [71]: 5-6 yang dalam redaksinya berisi tentang keluhan nabi Nuh as. tentang umatnya yang enggan menyembah Allah.

Pandangan di atas, kemudian menjadi bahan kritikan baik dari kalangan ulama maupun masyarakat yang menjadi mad'u (obyek dakwah) setiap kali Jamaah ini berdakwah. Salah satu kelompok yang mengkritik keras terhadap praktek dakwah Jamaah tablig adalah kelompok salafi-wahabi, seperti yang dilontarkan Syaikh 'Alī bin Hasan al-Halabī al-Atharī bahwa segala amalan yang dilakukan Jamaah tablig itu bersumber dari hadis-hadis yang dhaif, begitupun dengan ayat-ayat yang dirujuknya. Ayat-ayat yang dirujuk Jamaah tablig dalam konsep khurūj dengan menetapkan jumlah hari dalam berdakwah itu, menurut Hasan al-Halabī merupakan kekeliruan mereka dalam memaknai dan memahami ayat. Sehingga Jamaah tablig dianggap sebagai sebuah gerakan yang menyimpang dan sesat karena pengikutnya mengerjakan amalan-amalan yang bid'ah. ${ }^{56}$

Kendatipun demikian, pandangan mereka terhadap sebuah ayat lebih banyak didasari dengan cara menelaah teks terjemahan ayat tersebut. Seperti dalam memaknai QS. al-

56 Lihat dalam almanhaj.or.id diakses pada Kamis, 18 April, 2019.
Syuara ayat 214, Āli 'Imrān ayat 110, Yūsuf ayat 108, dan ayat-ayat lain yang dalam redaksi ayatnya berisi seruan-seruan Allah untuk mengerjakan amar ma'rūf nahī munkar. Jalan penafsiran Jamaah tablig seperti itu dapat terlihat dari bagaimana mereka menyampaikan sebuah materi dakwah ketika bayān, jawlah, ataupun saat memberi jawaban atas pertanyaan penulis saat mewawancarai mereka.

Memang, model pemahaman yang diterapkan Jamaah tablig terhadap sejumlah ayat yang dijadikan basis argumennya, dapat dikatakan bahwa mereka lebih melihat kepada aspek literal-tekstual, dari pada makna substanstif-kontekstual. Dengan kata lain, subyektivitas penafsiran mereka lebih terlihat, dari pada obyektivitasnya. Walaupun sebenarnya, penulis menelaah bahwa dalam menafsirkan ayat, Jamaah tablig memiliki kesamaan dengan beberapa penafsir semisal Sayyid Quthb dan Imam al-Tabarī. Ini terlihat dari bagaimana jalan pemikiran Jamaah tablig ketika memaknai isi kandungan QS. Āli 'Imrān [3]: 104 dan 110.

Jamaah tablig, sebagai gerakan dakwah Islam yang lahir sebagai respon atas pemahaman terhadap realita kehidupan masyarakat dipadu dengan pemaknaan terhadap teks-teks keagamaan yaitu al-Qur'an dan al-Sunnah, kiranya patut diapresiasi. Gerakan dakwah yang hingga kini bisa mempunyai pengikut hampir di setiap negara ini, tidak terlepas dari pemikiran yang ditawarkannya kepada para pengikutnya. Ada dua prinsip yang sangat fundamental bagi Jamaah tablig yaitu tidak melibatkan diri dalam politik praktis dan tidak membahas masalah keagamaan yang bersifat khilafiyah.

Selain itu, penulis juga memerhatikan bahwasannya pendekatan dakwah dan ibadah 
yang digunakan adalah dengan cara tasawuf, tidak dengan politik, sosial, ataupun budaya. Sebab, sebagaimana penulis sadur dari keterangan beberapa Jamaah, mereka sangat meyakini bahwa tasawuf adalah cara untuk mewujudkan hubungan dekat dengan Allah swt dan cara untuk memeroleh kelezatan iman. Berangkat dari sebuah gerakan yang mengutamakan amalan ibadah mahdah seperti memperbanyak zikir layaknya para sufi kemudian menjadi alasan terhadap jalan penafsiran mereka yang meninjau suatu ayat secara literal-tekstual.

Pada akhirnya, dari catatan penulis tentang gerakan ini perlu digarisbawahi bahwa Jamaah tablig pada dasarnya tidak menganggap bahwa dirinya adalah sebuah jamaah atau komunitas Islam baru. Ia hanyalah mengembangkan ajaran dakwah sebagaimana yang telah dibuat oleh Nabi Muhammad saw., dengan tujuan untuk mereformasi perilaku individu dan mengembangkan masyarakat Muslim yang ideal sesuai dengan ajaran Nabi Dengan demikian, tidak ada perbedaan prinsip antara gerakan Jamaah tablig dengan gerakan dakwah lainnya dalam hal beribadah, perbedaanya hanya terletak pada metode mereka dalam merealisasikan ayat-ayat dakwah yang tertulis dalam al-Qur'an.

\section{Simpulan}

Ayat-ayat dakwah yang dirujuk dan dipahami Jamaah tablig pada dasarnya sama dengan kebanyakan gerakan dakwah lainnya. Dalam memahami sejumlah ayat yang kemudian dijadikan sebagai basis argumennya, dapat dikatakan bahwa mereka lebih melihat kepada aspek literal-tekstual, dari pada makna substanstif-kontekstual. Walaupun sebenarnya, penulis menelaah bahwa di beberapa ayat, pandangan Jamaah tablig mempunyai kemiripan dengan beberapa penafsir semisal Sayyid Quțub dan Imam alȚabarī. Ini terlihat dari bagaimana jalan pemikiran Jamaah tablig ketika memaknai isi kandungan ayat utama untuk berdakwah dalam QS. Āli ‘Imrān ayat 104 dan 110.

Adapun lahirnya konsep dakwah dengan nama khurūj dan jawlah ialah merupakan suatu bentuk representasi dari cara meneledani kisah-kisah perjuangan dakwah para nabi terdahulu termasuk rekam jejak Rasulullah saw. bersama para sahabatnya pada waktu berdakwah menyebarkan risalah agama Islam di kota Mekkah. Karenanya, perihal ayat-ayat $k h u r u \bar{j}$ dan jawlah, Jamaah tablig mengutip beberapa ayat yang secara teks berisi tentang kisah perjuangan dakwah para nabi. Ayat-ayat tersebut antara lain QS. Nūḥ [71]: 5-6, QS. Hūd [11]: 51, dan QS. Yūsuf [12]: 108. Selebihnya Jamaah tablig tetap mengutip ayatayat yang dalam redaksinya berkaitan dengan dakwah.

Berdasarkan pengamatan di lapangan dan beberapa keterangan yang penulis sadur dari Jamaah tablig Masjid Kebon Jeruk. Gerakan yang didirikan Syaikh Muhammad Maulana Ilyas ini memiliki model pendekatan dakwah dengan mengutamakan ibadah-ibadah mahdhah bahkan cenderung tasawuf. Label tasawuf ini bisa jadi didasari dari sang pendirinya sendiri yang semasa hidupnya berafiliasi dengan Tariqah Naqhshabandiyyah, sebuah tarekat sufi yang menganggap ketaatan syariat sebagai bagian integral dari praktek sufi mereka.

\section{Pustaka Acuan}

Ansari, Furqan Ahmad. Pedoman BerTablig, Malaysia: Dewan Pakistan 1995.

Ardani, Moh. Akhlak Tasawuf: Nilai-Nilai Akhlak/Budi Pekerti dalam Ibadat dan Tasawuf, Jakarta: CV. Karya Mulia, 2005. 
Asmi, Rudi Wawancara pada 17 Januari 2019. Atsary, Abu Umamah Abdurrahim. Jamaah tablig; kenyataan dan pengakuan, Yogyakarta: Hikmah Ahlussunnah, 2015.

Aziz, Abdul "The Jamaah tablig Movement in Indonesia," Studia Islamika, 11:3, 2004.

Hasanah, Umdatul. "Keberadaan Kelompok Jamaah tablig dan Reaksi Masyarakat (Perspektif Teori Penyebaran Informasi dan Pengaruh)"

http://mesjidjamikebonjeruk.blogspot.com/20 09/09/artikel-masjid-kebon-jeruk.html pada Rabu, 06 Maret, 2019.

https://almanhaj.or.id/1221-jamaah-Tabligtidak-berdiri-berdasarkan-kitabullahdan-sunnah-rasulnya.html diakses pada Selasa, 05 Maret 2019.

Ilyas, M. Azizzullah. "Kompetensi Juru Dakwah dalam Pandangan Jamaah tablig", Jurnal Dakwah dan Komunikasi, Vol.2, No. 01, Desember 2017.

Junaedi, Didi. Memahami Teks, Melahirkan Konteks: Menelisiki Interpretasi Ideologis Jamaah tablig,

Al-Kandahlawi, Mawlana Muhammad Yusuf. Mudzakaroh Enam Sifat Para Sahabat dan Amalan Nurani, Bandung: Pustaka Ramadhan, 2006.

Al-Kandahlawī, Mawlana Muhammad Zakariā. Fadhilah Amal, terj. tim penerjemah Masjid Jami' Kebon Jeruk Jakarta. Yogyakarta: Ash-Shaf, 2012.

Katarina, Widya Studi Bentuk dan Elemen Arsiteksur Masjid di Jakarta Abad 1820. Binus University, Jurnal ComTech, vol. 3 no. 2, Desember 2012.

Khurūj.tripod.com/id2.html yang dikutip pada Senin, 11 Maret, 2019.

Kurniawan, Angga. "Teologi Jamaah tablig (Studi Kasus di Pesantren Sunanul
Husna Manjangan", Skripsi Fakultas Ushuluddin, UIN Jakarta, 2017. almanhaj.or.id diakses pada Kamis, 18 April, 2019.

Mustafa, Ali. "Model Dakwah Silaturahmi Jamaah tablig dalam Jawlah Khususi”, Jurnal As-Salam, 2017, Vol. I, 81.

Al-Nadwi, Sayyid Abul Hasan. Riwayat Hidup dan Usaha Dakwah Maulana Muhammad Ilyas, Yogyakarta: AshShaff, 1999.

Nurdin, "Reaksi Sosial terhadap Pelaksanaan Khurūj Fi Sabilillah dalam Gerakan Dakwah Jamaah tablig di Kabupaten Gowa", Skripsi Universitas Islam Negeri Alauddin Makassar, 2017.

Al-Qurțubī, Syaikh Imam. Al-Jāmi' li Aḥkām Al-Qur'ān, terj. Dudi Rosyadi, dkk,

Razak, Yusran. Jamaah tablig, Ajaran dan Dakwahnya, Disertasi Doktor, Sekolah Pascasarjana UIN Syarif Hidayatullah Jakarta, 2008.

Riḍā, Rashīd. Tafsìr Al-Qur'ān al-Hakīm alSyahir bi al-Tafsīr al-Manār, Kairo: Hai'ah Misriyyah al-'Ammah li alKitab, 1990.

Riyadi, Slamet Wawancara pada 18 Januari 2019.

Rofiah, Khusniati. Dakwah Jamaah tablig dan Eksistensinya di Mata Masyarakat, STAIN Ponorogo Press.

Sadelih, Wawancara pada 16 Januari 2019.

Shahab, An Nadhr M. Ishaq. Khurūj Fī Sabilillah, Bandung: Pustaka Ramadhan, 2007.

Shihab, M. Quraish. Tafsir al-Misbah, Pesan, Kesan, dan Keserasian Al-Qur'an.

As-Sirbuny, Abdurrahman. Kupas Tuntas Jamaah tablig, Cirebon: Pustaka Nabawi, 2012.

Yunus, Muhammad. Wawancara pada 17 Januari 2019. 